\title{
PRISPEVEK K RAZUMEVANJU ZGODOVINSKE POSELITVE JUŽNEGA DELA RIBNIŠKE MALE GORE
}

\author{
mag. Milan Hornak*, dr. Uroš Stepišnik** \\ * Oddelek za arheologijo, ** Oddelek za geografijo, Filozofska fakulteta \\ Univerze v Ljubljani, Aškerčeva 2, SI-I000 Ljubljana \\ e-mail: hornak.milan@gmail.com; uros.stepisnik@ff.uni-lj.si
}

Izvirni znanstveni članek

COBISS 1.01

\begin{abstract}
Izvleček
Članek predstavlja možnosti vizualnega preučevanja arheološkega potenciala ali arheološke valorizacije kraškega območja južnega dela Ribniške Male gore. Raziskovano območje je znano po jamskih najdiščih Lisičja jama in Koblarska jama. Do sedaj niso bili identificirani ostanki prazgodovinskih naselbin na površju. S terenskim preučevanjem in s pomočjo GIS-ov avtorja poskušata opredeliti potencialne možnosti za zgodovinsko poselitev na preučevanem območju. Drugi vidik njunih raziskav predstavlja sistematično pregledovanje horizontalnih jam na Koblarskem hribu. S preučevanjem naravnih, predvsem geomorfnih, in antropogenih procesov ter oblik v jamskih okoljih ugotavljata možnost zgodovinske rabe jam.
\end{abstract}

Ključne besede: Ribniška Mala gora, arheologija, geomorfologija, kras, jame

\section{A CONTRIBUTION TO THE UNDERSTANDING OF HISTORICAL SETTLEMENT IN THE SOUTHERN PART OF RIBNIŠKA MALA GORA}

\begin{abstract}
The paper presents possibilities of visual assessment of archaeological potential, i.e. archaeological valorization, of southern part of Ribniška Mala gora karstic area. In archaeological literature, the study area is known only for two archaeological sites in caves Lisičja jama (Iron Age) and Koblarska jama (roughly late Copper and early Bronze Age). Until now, remains of prehistoric settlements have not been identified on the surface. With field investigation of karstic surface and application of geographic information systems the authors are trying to define the potential for past settlement of the area. Another aspect of the research is concerned with systematical research of horizontal cave passages in the Koblarski hrib area. Through the investigation of natural and anthropogenic features and processes in cave environments the authors are trying to establish historical use of caves.
\end{abstract}

Key words: Ribniška Mala gora, archaeology, geomorphology, karst, caves 


\section{UVOD}

Arheološki potencial Kočevske regije lahko v določeni meri razumemo kot refleksijo na prostorsko razporeditev naselij, človekovo delovanje in njegovo poseganje v kulturno pokrajino v preteklosti. Večina znanih arheoloških najdišč je bila odkritih v neposredni bližini cestnih komunikaciji ali naselij. Razlog za to je predvsem v značilnostih naravnega okolja, ki v večini predstavlja hribovito in težko prehodno območje kraškega sveta, poraščeno z obširnimi in gostimi gozdovi. Že leta 1910 je Jernej Pečnik (1912, 26), ki je na začetku 20. st. pri iskanju arheoloških spomenikov obiskal tudi to območje, napisal: »... tu so silno pusti kraji, samo hribi in gozdovi, in se tudi prav malo ostankov najde iz predzgodovine.«. Skoraj pred sto leti napisane besede, ki govorijo o stanju raziskav na območju Koblarskega hriba oz. južnega dela Ribniške Male gore (v nadaljevanju raziskovano območje), so še zmeraj aktualne. Od Pečnikovih raziskav na tem območju sta znani le dve najdišči, in sicer Koblarska jama (Jamnik, Leben-Seljak, Bizjak in Horvat 2002) ter Lisičja jama (Leben 1970).

Avtorja je takšno izrazito pomanjkanje podatkov pripeljalo do vprašanja, ali je odsotnost arheoloških najdišč le posledica dosedanjega stanja raziskav ali je odvisna od drugih dejavnikov? Z računalniškim modeliranjem in izvajanjem terenskega prepoznavanja, ki so zajemali vizualno preučevanje in valorizacijo potencialnih možnosti poselitve na določenih legah, sta avtorja skušala interpretirati prostorski pomen raziskovanega območja v odnosu do sosednjih regij, saj se nahaja na stičišču Suhe krajine, Dobrepolja in Kočevsko-Ribniškega polja. Poseben del raziskav je bil namenjen preučevanju naravnih, predvsem geomorfoloških, in antropogenih oblik in procesov $\mathrm{v}$ horizontalnih jamah na raziskovanem območju ter njihovi interpretaciji.

\section{OPIS RAZISKOVANEGA OBMOČJA}

Ribniška Mala gora je izrazito podolgovato sleme, ki se vleče v dinarski smeri 24 km daleč in je v povprečju 3 do $4 \mathrm{~km}$ široko. Zavzema okoli $115 \mathrm{~km}^{2}$ površine. Predstavlja prehod med nizkim planotastim dolenjskim krasom na eni strani in visokim notranjskim krasom na drugi, tako po višinah kot po oblikovanosti površja. V večjem delu ima relativne višine med 300 in 500 m nad okoliškim reliefom. Na zahodni strani meji na Ribniško polje in Velikolaško pokrajino, na vzhodni strani pa na Dobrepolje in južni del Suhe krajine. Preučevano območje obsega skrajni južni del Male gore s toponimom Koblarski hrib, kjer osrednje sleme preide v dve manjši: zahodni Kumac in vzhodni Malogorski hrib. Preučevano območje je v celoti zgrajeno iz spodnjekrednih temno sivih gostih in lepo skladovitih bituminoznih apnencev z vpadom skladov okrog 20 stopinj proti jugozahodu (Buser in sod. 1968).

Ribniška Mala gora je kraški masiv brez površinskih vodnih tokov. Na njenih vzdolžnih robovih, ki imajo predvsem dinarsko smer, je mnogo vodnih pojavov, predvsem ponorov na zahodni strani in izvirov na vzhodni. Na jugozahodnem obrobju, $v$ bližini preučevanega območja, se nahaja cela vrsta majhnih površinskih tokov, ki pritekajo iz neprepustnega površja Ribniškega polja in poniknejo v podnožju Male gore. Ob visokih vodostajih se vode Zadnje Rinže površinsko pretakajo ob vznožju jugovzhodnega dela Ribniške Male gore z Ribniškega na Kočevsko polje. Na vzhodnem obrobju pa je cela vrsta izvirov in izvirnih 
kraških jam (Kranjc 1980). V hidrografskem pogledu je Ribniška Mala gora pomemben člen, saj se skoznjo pretakajo vode iz zahodnega, neprepustnega dela Ribniškega polja proti Dobrepolju in Krki (Novak 1970; 1974; 1991). Vsekakor so za poselitev in antropogeno rabo na brezvodnem kraškem površju Ribniške Male gore pomembni lokalni vodni viri, ki so vezani na vodna zajetja v jamah in v kalih na površju.

Slika 1: Lega preučevanega območja

Figure 1: Location of the study area

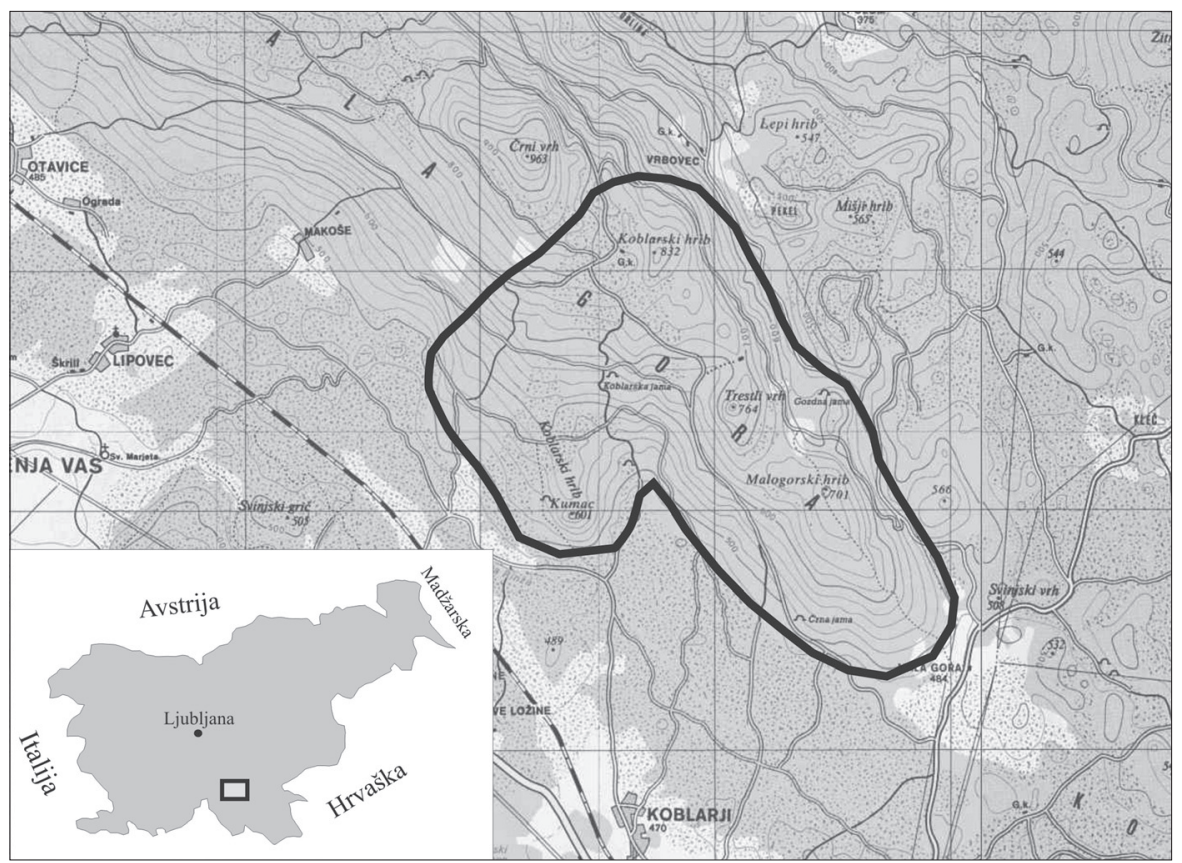

Površje na preučevanem območju je skalnato, prekrito s škrapljami, prsti so plitve. Na površju z manjšim naklonom se pojavlja večja gostota vrtač in manjših udornic, ki jih v dneh zapolnjujejo debelejše ilovnate prsti. Zaradi odsotnosti prepereline in površinskih vodnih tokov na površju preučevanega območja ni mehanskih pobočnih procesov v smislu spiranja ali drsenja prepereline ali vodne erozije in akumulacije. Na površju je prevladujoč proces kemično preperevanje oz. korozija, dinamika vertikalne kemične denudacije na območju pa znaša 50 do $60 \mathrm{~B}\left(\mathrm{~m} \mathrm{Ma}^{-1}\right)($ Gams 2004, 74). Po katastru jam Jamarske zveze Slovenije (2007) se v južnem delu Ribniške Male gore nahaja okrog 100 jamskih objektov, med katerimi prevladujejo vadozna brezna. Med jamami je tudi nekaj ostankov freatičnih sistemov, to je bolj ali manj vodoravnih jam, ki kažejo na pretekle hidrološke razmere na območju Ribniške Male gore. Gostota, dimenzije in razporeditev jam ter ilovnate zapolnitve v njih kažejo, da je bilo to območje tudi v geološki preteklosti hidrološko pomembno za prevajanje voda od zahoda proti vzhodu. 


\section{REZULTATI TERENSKEGA REKOGNOSCIRANJA}

Terensko rekognosciranje je $\mathrm{v}$ precejšnji meri oteženo zaradi težke prehodnosti in poraščenosti raziskovanega območja. V nekaterih delih je prehod mogoč le po gozdnih cestah ali gozdarskih vlakah. Študij in primerjava starejših kartografskih podatkov, predvsem franciscejskega katastra (ARS 2007: Koblarji - AS 3000/N118; Polom - AS 3000/N47; Mala Gora-AS 3000/N151) in vojaških topografskih kart iz leta 1974 (Topografska karta 1:25.000 1974) s sodobnimi iz leta 2004 (Državna topografska karta 1:25.000 2004), sta pokazala, da se je mreža gozdnih poti v zadnjih tridesetih letih temeljito preoblikovala, saj so nekatere gozdne ceste in vlake nove, medtem ko nekatere starejše ne obstajajo več. To je povzročalo dodatne težave pri določanju lege nekaterih jam (Črna jama, Knežja jama, Lisičja jama). Pri lociranju in interpretaciji človekovih posegov v preteklosti je bila zaradi goste poraščenosti območja popolnoma onemogočena uporaba ortofoto posnetkov ali drugih orodij daljinskega zaznavanja. Za to smo se pri terenskem rekognosciranju osredotočili predvsem na pregled izbranih leg uravnanih površin, ki bi omogočale trajnejšo rabo prostora, in na pregled vseh notranjih delov večjih horizontalnih jam ter njihove neposredne okolice.

Pri določevanju potencialnih leg zgodovinske poselitve smo izhajali predvsem iz njihove predvidevane strateške pozicije. Upoštevani so bili nekateri pragmatični poselitveni vidiki, npr. zahtevnost dostopa in relativna oddaljenost od komunikacijskih povezav. Glede na značilnosti kraškega površja so morale takšne lege izpolnjevati še vsaj dve od naslednjih determinant: izrazita višinska razlika nad okolico, ravno površje z obsegom najmanj 100 $\mathrm{m}^{2}$ ter bližina vodnega vira (jama s kapnico oz. vadozno vodo, kali na površju). Na podlagi definiranih pogojev smo podrobneje pregledali naslednje potencialne lege: hrib Kumac (600 m), Malogorski hrib (707 m), Tresti vrh (764 m) in Koblarski hrib (827 m) (slika 2). Rezultati terenskih pregledov so pokazali, da nikjer niso vidni sledovi dolgotrajnejše poselitve oziroma izrazitega antropogenega preoblikovanja prostora. Kljub temu obstaja možnost njihove rabe za bivalne ali naselbinske oblike (lesene stavbe), katerih ostanke ali obstoj bi lahko identificirali le z uporabo drugačnih raziskovalnih metod, kot so geofizikalno testiranje ali arheološko izkopavanje.

Pri opredeljevanju ravnih površin smo za izhodišče uporabili digitalni model reliefa z natančnostjo $15 \times 15$ m, izdelan s pomočjo topografskih kart v merilu 1:25.000, na podlagi katerega smo izdelali karto naklonov. Primerjava dobljenih digitalnih podatkov o naklonih površja z dejansko situacijo na terenu je potrdila pomanjkanje obsežnejših ravnih površin tudi na krajih, kjer smo na podlagi pregleda topografskih kart uravnane površine predvidevali. Izkazalo se je, da so prav na teh legah najbolj razvite površinske skalne oblike, predvsem škraplje, vrtače ali manjše udornice. Digitalno določene ravne površine se v manjšem obsegu nahajajo med vrtačami in $v$ njihovih dneh.

Poleg ocenjevanja in arheološke valorizacije potencialnih površinskih oblik je zelo pomemben del raziskav predstavljalo sistematično pregledovanje sedmih horizontalnih jam na raziskovanem območju: Koblarska jama (kat. št. JZS 94), Lisičja jama (kat. št. JZS 6155), Vančeva jama (kat. št. JZS 3887), Kevderc pri Vančevi jami (kat. št. JZS 3850), Črna jama (kat. št. JZS 2934), Knežja jama (kat. št. JZS 130) in Vrbovška jama (kat. št. JZS 7013) (slika 3). 
Slika 2: Karta uravnanih območij in dominantnih leg

Figure 2: Map of flattened areas and dominant locations

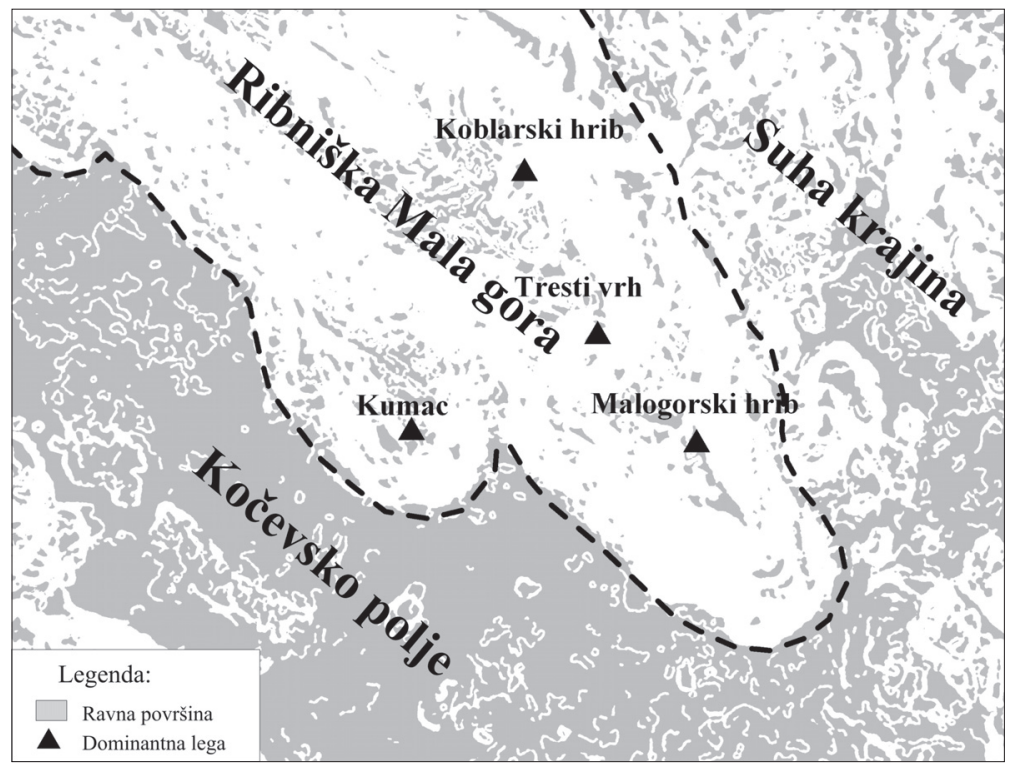

Vse pregledane jame so odlomki freatičnih jamskih sistemov. Na podlagi sedimentov $\mathrm{v}$ jamah in usmerjenosti faset lahko $\mathrm{v}$ grobem sklepamo, da so prevajale vodo od zahoda proti vzhodu, torej so delovale $\mathrm{v}$ enakih hidroloških pogojih, kakršni so na tem območju še danes. Prevladujejo paragenetsko preoblikovani vodoravni rovi, kar kaže na intenzivno vtekanje alohtonih sedimentov v sistem. Dna rovov so zapolnjena z ilovnatim materialom, ki je mestoma prekrit s podornim materialom ali sigo. Ilovica je bila $\mathrm{v}$ jamah mestoma izprana z vadozno vodo. Pogosti so močnejši dotoki vadozne vode oz. deževnice, ki se zbirajo v ponvicah ali pa so ujeti v lesenih umetnih koritih. V Koblarski in Črni jami so še ohranjena korita pod močnejšimi curki vadozne vode. V Vančevi, Koblarski, Vrbovški in Knežji jami pa so se oblikovale večje ponvice, v katerih je ujeta voda. V severnem rovu Vrbovške jame so vidni ostanki umetne zajezitve iz zloženega kamenja nad naravno sigovo ponvico, ki je služila zadrževanju večjih količin padavinske vode v jami. Tudi sigove tvorbe nad ponvico kažejo na daljše umetno zadrževanje višjega vodostaja v tem jamskem rovu. Skupni imenovalec vseh raziskanih jam je, poleg pretežno horizontalnih rovov in nezahtevnega vhodnega dela jam, tudi prisotnost vode, ki se nahaja ali v jami kot kapnica ali v njihovi bližini v obliki kalov, narejenih na zaplatah ilovice na kraškem površju. Eden od večjih kalov na raziskovanem območju je Vrbovška luža v bližini Vrbovške jame, mimo katere je v preteklosti potekala glavna prometna komunikacija Dobrepolje-Vrbovec-Koblarji-Kočevje.

Na zahodnem pobočju hriba Kumac se v neposredni bližini nahajata Vančeva jama (kat. št JZS 3887, 555 m, Kumac) in Kevdrc pri Vančevi jami (kat. št JZS 3850, 550 m, Kumac). Kljub temu da sta jami vodoravni in se $\mathrm{v}$ Vančevi jami nahajajo številne ponvice, zapolnjene $\mathrm{z}$ 
vodo, v obeh jamah nismo našli arheoloških sledov človekovega delovanja. Dostop v Vančevo jamo predstavlja nekajmetrska poševna stopnja, pod katero se nahaja zid z železnimi vrati, ki so ga v šestdesetih letih 20. st. postavili člani Jamarskega kluba Kočevje zaradi zaščite jame. Ob vhodu je bil v času zaprtja jame izkopan prehod v podorni material, ki ga prekriva siga. Na profilu izkopa niso bili opaženi sledovi starejših antropogenih posegov v jami.

\section{Slika 3: Senčen digitalni model reliefa območja z lokacijami raziskanih jam}

Figure 3: Shadowed digital elevation model of the study area with locations of investigated caves

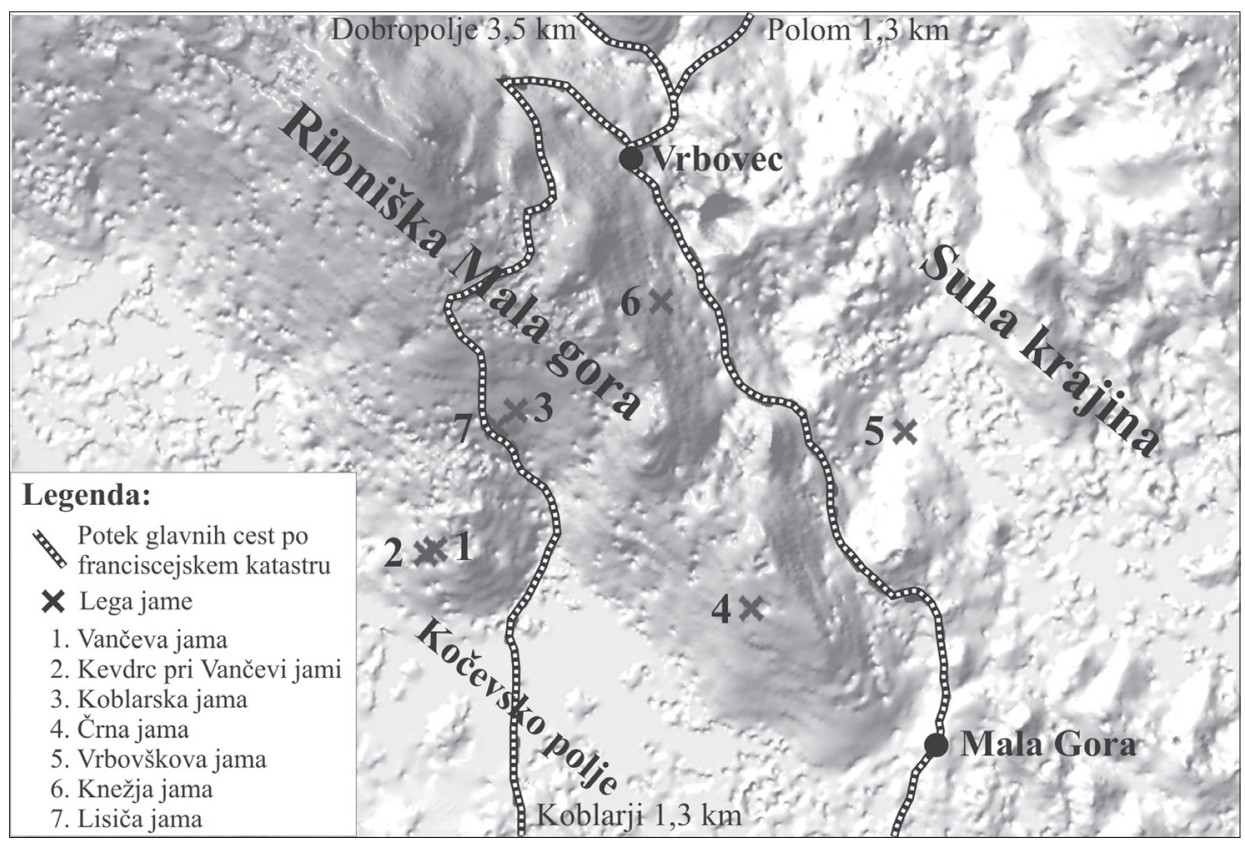

Do nepričakovanih zapletov je prišlo pri iskanju železnodobnega grobišča Lisičja jama (kat. št. JZS 6155, 625 m, Kumac). Med analizo podatkov o jami se je izkazalo, da so za njeno lego navedene kar tri različne lokacije. V Arheoloških najdiščih Slovenije (ANSL 1975, 237) najdemo opis pozicije jame, ki naj bi se nahajala $1,6 \mathrm{~km}$ in $359^{\circ}$ od Koblarjev na nadmorski višini $470 \mathrm{~m}$. Po tem opisu je določena in zabeležena pozicija $\mathrm{v}$ enem od dopolnilnih zapisnikov v Katastru jam JZS (2006). Drugo morebitno lokacijo je določil F. Leben (Pavel Jamnik, ustni vir 2007) in jo identificiral kot Malo Željnsko jamo. Tako lokacijo najdemo tudi v Arheološkem katastru Slovenije (ARKAS 2007). Tretjo morebitno lego je določil F. Šušteršič (1994), ki je izhajal iz podatkov navedenih v A zapisniku za Lisičjo jamo (Kataster jam JZS 2007). V njem je natančen opis dostopa do jame iz leta 1976, ko so jo obiskali in izmerili kočevski jamarji.

Pri terenskih pregledih smo preverili vse zgoraj omenjene lokacije in ugotovili, da se niti na eni ne nahaja jama, ki bi odgovarjala opisu iskane jame. Podobno negativen je bil 
rezultat v primeru približno $15 \mathrm{~km}$ oddaljene Male Željnske jame, ki je pretočna jama z aktivnim vodnim tokom. Za to smo se odločili primerjati opis dostopa do jame, ki je naveden v najbolj verodostojnih podatkih iz leta $1976 \mathrm{~s}$ takratnimi topografskimi kartami, kar nas je po večkratnih poskusih pripeljalo do ponovnega odkritja Lisičje jame. Jama se nahaja v vrtači, ki je zaradi skalnih sten dostopna le z ene strani. Skozi vhod velikosti $2 \mathrm{~m}$ x 1,5 m se pride $\mathrm{v} 17 \mathrm{~m}$ dolg rov. V vhodnem delu so ob levi steni vidni sledovi sonde, ki jo je $\mathrm{v}$ zadnjih letih 19. st. izkopal koblarski učitelj Wolsegger. Pri izkopavanju so bile najdene tri žare z dvema ročajema, ki so pri dvigovanju razpadle (ANSL 1975, 237). K. Moser je žare sprva datiral v prazgodovinsko obdobje, vendarle jim je pozneje priznal keltsko-rimsko starost (Moser 1897, 10; citirano po Leben 1970, 31).

Arheološko najbolj znana jama na raziskovanem območju je Koblarska jama (kat. št JZS 94, 660 m, Koblarski hrib), v kateri so bila prva izkopavanja že ob koncu 19. st. Takrat so odkrili osem človeških skeletov. Leta 1901 sta v jami sondirala J. Müller in F. Schulz, ki sta iz jame odnesla nekaj zabojev antropološkega gradiva (Leben 1978, 18-19). O človeških ostankih govorijo tudi poročila obiskovalcev jame v mlajšem obdobju (Kataster jam JZS 2007). Dejstvo, da so bile človeške kosti razmetane po jami, je leta 2000 vodilo do sistematičnega pregledovanja vseh rovov. Dokumentirane so bile lege s koncentracijo antropološkega in arheološkega materiala. Najdbe so bile pobrane le na površju, tako da so brez zadostnih stratigrafskih podatkov. Zato so toliko pomembnejši izsledki antropoloških analiz, ki so pokazali, da dobljeni kostni ostanki pripadajo najmanj trinajstim posameznikom (Jamnik in sod. 2002, 31, 43). Zelo vprašljiva pa je njihova časovna opredelitev. Na mestih, kjer so bili najdeni kostni ostanki, so bili tudi številni fragmenti keramike, datirani v bakreno dobo ali posamezno v pozno bronasto in poznoantično dobo (Jamnik in sod. 2002, 43).

Med našimi raziskavami smo v zaključnih delih severnega rova identificirali spremenjeno morfologijo jame. Dostop do tega dela jame predstavlja ožina velikosti $1 \mathrm{~m}$ x 1,5 m, ki vodi v manjšo dvorano. Ob začetku ožine je antropogeno nasutje ilovnatega materiala, ki skoraj $\mathrm{v}$ celoti zapira dostop do rova. V dvorani je ob zahodni steni ilovnato nasutje, ki je vsekakor antropogenega nastanka, saj nad njim ni nikakršnega dotoka vode ali ilovice iz jamskega stropa.

Na severovzhodnem delu raziskovanega območja, v vzhodnem pobočju Koblarskega hriba okrog 1 km južno od Vrbovca, se nahaja Vrbovška jama (kat. št JZS 7013, 650 m, Koblarski hrib). Po napisih v jami vemo, da so jo obiskovali že v sredini 19. st. Čeprav do sedaj ni bila registrirana kot arheološko najdišče, v zapisnikih Katastra jam JZS (2007) najdemo poročila o najdbah prazgodovinske keramike $\mathrm{v}$ vhodnih delih jame ob zaključku melišča. Prav v tem delu jame smo v ilovnatem materialu izkopali testni jarek v velikosti $1 \mathrm{~m}$ x $1 \mathrm{~m}$ do globine $50 \mathrm{~cm}$, kjer se je pojavilo intaktno podorno nasutje. S sondiranjem smo odkrili ostanke osmih kulturnih plasti. V treh plasteh v skupni globini do $-25 \mathrm{~cm}$ (slika 4: SE 1000, SE 1006 in SE 1008) so se mestoma nahajali fragmenti poznobronastodobne keramike. Glede na maloštevilne najdbe in razkrito stratigrafsko situacijo, ki ne kažejo sledov dolgotrajne poselitve, domnevamo, da je bila jama uporabljena le za občasno skrivališče. 
Sledove človeškega delovanja neznane starosti smo našli tudi v spodnjih vzhodnih delih Vrbovške jame in v njenem severnem delu. V spodnjih delih jame so tla zapolnjena z ilovnatim materialom, ki je v zadnjem delu jame antropogeno premeščen ob južno steno. $V$ višjem severnem delu jame se prav tako pojavljajo zaplate ilovnatega materiala na meliščnatem pobočju, ki so morale biti antropogeno premeščene, saj se v naravnih razmerah ilovica in podorni bloki melišča odlagajo $\mathrm{v}$ povsem različnih oblikah. V skrajnem severnem delu rova pa se nahaja večja, z vodo zapolnjena ponvica. Kalcitne oblike na stenah jame in premeščen material ob izteku ponvice nakazujejo, da je bil $\mathrm{v}$ tem delu jame umetno urejen zbiralnik vode, nivo vode pa je bil vsaj $1 \mathrm{~m}$ višji od sedanjega. Za kronološko opredelitev morfoloških sprememb v jami bi bile potrebne dodatne terenske raziskave.

Slika 4: Profil testnega jarka z označenimi stratigrafskimi enotami v Vrbovški jami (foto: Milan Hornak)

Figure 4: Profile through test trench in Vrbovška jama with marked stratigraphical units (photo: Milan Hornak)

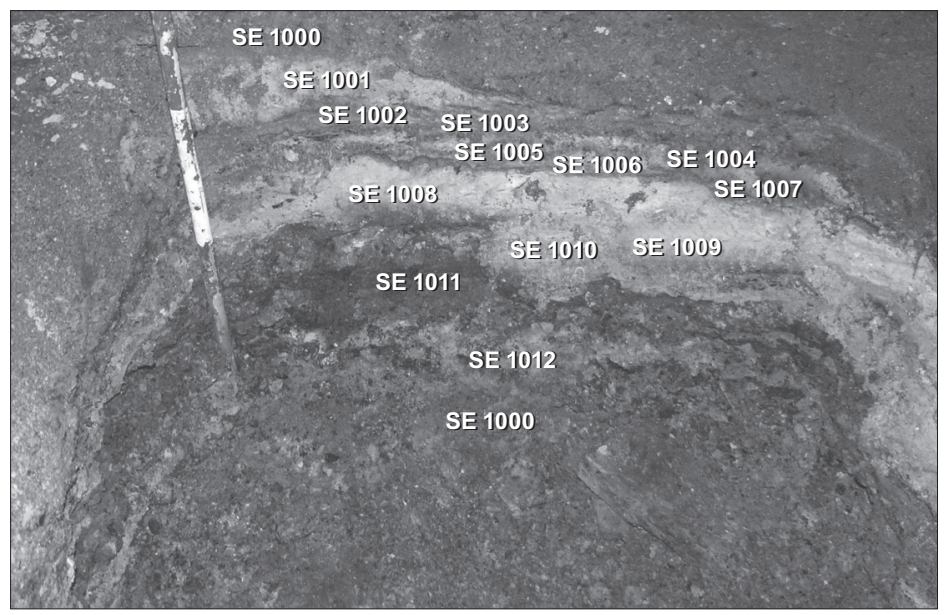

Okrog 60 višinskih metrov pod vrhom Malogorskega hriba se v zahodnem pobočju nahaja Črna jama (kat. št JZS 2934, 648 m, Malogorski hrib). Ozek vhod v jamo je v manjši vrtači pod steno, a se po nekaj metrih razširi v enoten rov dimenzij okrog $15 \mathrm{~m}$ x $5 \mathrm{~m}$, ki je dolg $258 \mathrm{~m}$. To je najdaljša jama na preučevanem območju, ime pa je dobila po črnih sajastih stenah po celotni dolžini jame. V zapisnikih Katastra jam JZS (2007) malo pred začetkom 2. svetovne vojne se jama omenja kot lepa kapniška jama z imenom Frauengrotte. Predvojnih omemb o onesnaženosti jame s sajami ni. Ker smo na jamskih stenah našli napise iz časov NOB, sklepamo, da je jama služila kot zavetišče partizanov, ki so v jami ali pred njo tudi kurili. Na podlagi najdb lesenih korit pod vodnimi curki v vhodem delu jame lahko domnevamo, da je jama služila tudi za oskrbo z vodo. Korita niso toliko ohranjena, da bi lahko določili njihovo starost. V vhodnem delu jame je tudi premeščen ilovnat material, ki zapolnjuje tla, kar tudi nakazuje na intenzivno antropogeno rabo. 
Tik pod severnim robom manjšega slemena s toponimom Fjuršte, ki poteka od Malogorskega hriba proti severu, se odpira vhod v Knežjo jamo (kat. št JZS 130, 625 m, Malogorski hrib). Vhodni del jame je ilovnato pobočje, prekrito z organsko preperelino, ki se spušča do osrednjega dela jame. V tem delu jame je M. Bukovec leta 1929 odkril ostanke roga in črepinje lonca neznane starosti. Omenja tudi, da je jama služila kot skrivališče v času turških vpadov (Kataster jam JZS 2007). Jama je poleg primernosti za skrivališče vsekakor tudi potencialni vir vode na tem območju, saj so $\mathrm{v}$ zadnjem delu jame ponvice zapolnjene $\mathrm{z}$ vodo.

\section{POSKUS INTERPRETACIJE ZGODOVINSKE POSELITVE JUŽNEGA DELA RIBNIŠKE MALE GORE}

Za raziskovano območje Koblarskega hriba oziroma južnega dela Ribniške Male gore je $\mathrm{v}$ sedanjosti značilen težko prehoden teren $\mathrm{z}$ obširnimi in gostimi gozdovi ter $\mathrm{z}$ izrazito kamnitostjo kraškega površja. Te značilnosti ustvarjajo občutek odmaknjenosti in zapuščenosti in so v nasprotju s sosednjimi kraškimi polji, ki so za poseljevanje in kulturno rabo veliko bolj primerna. Po podatkih franciscejskega katastra iz leta 1841 je razvidno, da je skozi raziskovano območje potekala pomembna prometnica, ki predstavlja najkrajšo povezavo med srednjim delom Ribniško-Kočevskega polja, Suho krajino in Dobrepoljem. Cesta je še danes ohranjena, prehodna in v aktivni rabi. Zelo zanimivo je dejstvo, da se prazgodovinska najdišča Koblarska jama, Lisičja jama ter Vrbovška jama nahajajo prav v njeni bližini. To bi lahko nakazovalo prisotnost neke starejše komunikacije, ki je zelo verjetnopotekala podobno kot poznejša srednjeveška ali novodobna komunikacija.

Slika 5: Zasigano leseno korito v zahodnem rovu Koblarske jame (foto: Uroš Stepišnik) Figure 5: Drinking trough covered with flowstone in western passage of the Koblarska jama (photo: Uroš Stepišnik)

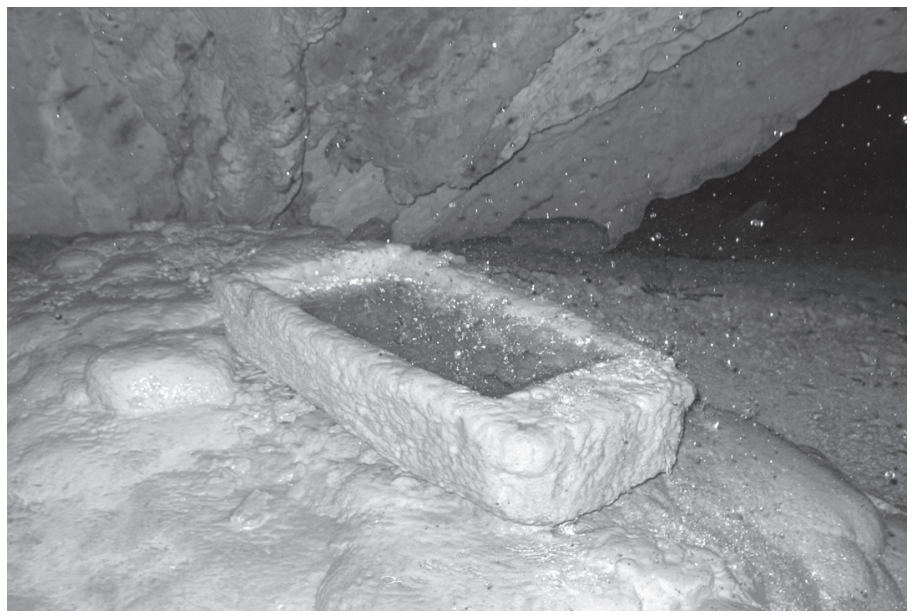


Vsekakor ni zanemarljivo, da je omenjena cesta iz leta 1841 potekala v bližini vodnih virov, ki se nahajajo kot kapnica v lahko dostopnih vodoravnih jamah ali na površju v obliki kalov. Tako je daljše zadrževanje na tem območju, poleg ceste, omogočala tudi možnost oskrbovanja z vodo. Ta dejstva nakazujejo na kratkotrajne oblike rabe prostora, kot je na primer možnost sezonske transhumance $\mathrm{v}$ zaledju ravninskega sveta koblarsko-ribniškega in dobrepoljskega območja. Hipotezo o pastirstvu bi lahko potrjevale maloštevilne najdbe in prisotnost lesenih korit v Črni in Koblarski jami (slika 5). V mlajših obdobjih se začnejo pojavljati še drugačni načini rabe prostora, predvsem oglarjenje, na kar nas opozarjajo številne oglarske kope, ugotovljene na raziskovanem območju.

Zaradi otežene prehodnosti in naravnih značilnosti južnega dela Ribniške Male gore je to območje služilo kot zavetišče oz. skrivališče v izjemnih razmerah, zlasti v jamah. Po ustnem izročilu je v času turških vpadov kot skrivališče služila Knežja jama (kataster jam JZS 2007). Podobno je v času NOB kot zavetišče partizanov služila Črna jama.

\section{SKLEP}

Avtorja sta v okviru poskusa reinterpretacije in valorizacije aktualnih in potencialnih arheoloških najdišč na območju južnega dela Ribniške Male gore prišla do zaključkov, da je sedanje stanje raziskav rezultat neraziskanosti območja in ne dejanske odsotnosti človekovega delovanja. S terenskim rekognosciranjem izbranih lokacij na površju in speleoloških objektov je bilo identificirano novo arheološko najdišče Vrbovška jama, ponovno je bilo locirano železnodobno grobišče Lisičja jama in v nekaterih vodoravnih jamah določena nova potencialna arheološko zanimiva mesta. Hkrati se je v grobem pokazal vzorec kulturne rabe prostora, ki je bil vezan na specifične lokacije izoliranih vodnih virov in prometnic v težko prehodnem, brezvodnem kraškem površju.

K reinterpretaciji zgodovinske poselitve raziskovanega območja je nedvomno prispevala prav interdisciplinarna raziskava, ki je vključevala področja arheologije, geomorfologije in uporabo geografskih informacijskih sistemov. Prav interdisciplinarno sodelovanje med arheologijo in geomorfologijo je ključnega pomena za razumevanje zgodovinskih procesov oziroma razvoja rabe prostora.

\section{Viri in literatura}

Arheološka najdišča Slovenije (ANSL). Državna založba Slovenije. Ljubljana 1975.

Arheološki kataster Slovenije (ARKAS). Medmrežje: http://arkas.zrc-sazu.si (2007).

Arhiv Republike Slovenije (ARS). Pregled map zemljiških katastrov 19. stoletja (digitalizirano arhivsko gradivo). Medmrežje: http://sigov3.sigov.si/cgi-bin/htqlcgi/arhiv/enos_isk_kat. htm (2007).

Buser, S. in sod. 1968: Osnovna geološka karta SFRJ 1 : 100.000. Tolmač lista Ribnica. Zvezni geološki zavod. Beograd.

Državna topografska karta Republike Slovenije v merilu $1: 25.000$. Ministrstvo za okolje in prostor, Geodetska uprava RS. Ljubljana 2004.

Gams, I. 2004: Kras v Sloveniji v prostoru in času. Založba ZRC. Ljubljana. 
Jamnik P., ustni vir, 2007.

Jamnik, P., Leben-Seljak, P., Bizjak, J. in Horvat, B. 2002: Koblarska jama na Kočevskem - prazgodovinsko grobišče in kultni prostor. Antropološka analiza skeletnih ostankov z opisom pridatkov. Arheološki vestnik 53, 31-49. Ljubljana.

Kataster jam Jamarske zveze Slovenije (JZS). A zapisniki in dopolnilni B zapisniki za Vančevo jamo, Kevdrc pri Vančevi jami, Koblarsko jamo, Vrbovško jamo, Črno jamo, Knežjo jamo in Lisičjo jamo (2007).

Kranjc, A. 1980: Prispevek k poznavanju razvoja krasa v Ribniški Mali gori. Acta carsologica 9, 27-85. Ljubljana.

Leben, F. 1970: Arheološka podoba dolenjskih jam. Naše jame 11, 25-40. Ljubljana.

Leben, F. 1978: Osteološke in kultne najdbe prazgodovinskega človeka iz kraških jam Slovenije in mejnega ozemlja. Arheološki vestnik 29, 13-35. Ljubljana.

Novak, D. 1970: Hidrogeološke značilnosti osrednje Dolenjske. Naše jame 11, 17-24. Ljubljana.

Novak, D. 1974: Nekaj o vodnih razmerah na Kočevskem polju. Acta carsologica 6, 367-394. Ljubljana.

Novak, D. 1991: Novejša sledenja kraških voda v Sloveniji po letu 1965. Geologija 33, 461478. Ljubljana.

Osnovna geološka karta SFRJ 1 : 100.000 list Ribnica. Zvezni geološki zavod. Beograd 1968. Pečnik, J. 1912: Vojvodina Kranjska v predzgodovinski dobi. Ljubljana.

Šušteršič, F. 1994: Delovni seznam jam južne Slovenije - dopolnila. Naše jame 36, 112-140. Ljubljana.

Topografska karta $1: 25.000$. Vojnogeografski institut. Beograd 1974.

\section{A CONTRIBUTION TO THE UNDERSTANDING OF HISTORICAL SETTLEMENT IN THE SOUTHERN PART OF RIBNIŠKA MALA GORA}

\section{Summary}

The paper presents the results of valorization and reappraisal of actual and potential archaeological sites in the southern part of Ribniška Mala gora. Detailed field survey of selected locations and speleological objects enabled the identification of a new archaeological site of Vrbovška jama and precise location of Lisičja jama site. Some other horizontal cave passages were recognized as potentially interesting sites for future archaeological research.

The study revealed the general pattern of cultural use of the area, which was connected with specific locations of isolated water sources and an old road in the hardly passable and waterless area. The results of this study also indicate that the hitherto existing interpretation of the limited settlement in this area by the archaeological literature has been the result of insufficient, or lacking, systematic field research. Efficient reinterpretation and valorization of historical land use of this karstic area was the result of interdisciplinary research involving archaeological, GIS and geomorphological methods. The study has shown that establishing closer links between archaeology and geomorphology is vital to better understanding of historical processes and changes in land use. 